\title{
Pingos in Peary Land, North Greenland
}

\author{
OLE BENNIKE
}

\begin{abstract}
Bennike, O. Pingos in Peary Land, North Greenland. Bull. geol. Soc. Denmark, vol, 32, pp. 97-99. Copenhagen, November, 15th, 1983. https://doi.org/10.37570/bgsd-1983-32-05

Pingos have previously been recorded from East and West Greenland, but not from North Greenland. Two finds in Peary Land therefore extend their distribution far northwards. The pingos were collapsed, they have presumably been of the open-system type, because they are situated in the bottom of valleys. It is concluded that pingos occur very rarely in northernmost Canada and Greenland
\end{abstract}

Ole Bennike, Geological Museum, Øster Voldgade 5-7, 1350 Copenhagen, Denmark. July 27th, 1983.

\section{Climate and permafrost}

The climate of Peary Land is distinctly high-arctic. The conditions at the pingo localities probably resemble those from Jørgen Brønlund Fjord, from where meteorological observations have been published (Fristrup 1952). There the mean annual temperature is $-15^{\circ} \mathrm{C}$, the temperature for July is $4-6^{\circ} \mathrm{C}$.

The permafrost is continuous. At Thule its thickness has been estimated to approximately $500 \mathrm{~m}$ (Roethlisberger 1961). The climate of Peary Land is more severe than at Thule, and a somewhat greater thickness can generally be expected. However, the two finds were located in large valleys, where the permafrost is probably rather thin.
The active layer reaches a maximum thickness of approximately one meter.

\section{Observations}

The location of the pingos appear from fig. 1 . Loc. 1: Vølvedal, $83^{\circ} 03^{\prime} \mathrm{N}, 34^{\circ} 30^{\prime} \mathrm{W}$.

A single collapsed pingo was observed (see fig. 2). The topografi of the area is alpine. The pingo is situated on a glaciofluvial plain in the bottom of the Vølvedal valley, at an altitude of c. $50 \mathrm{~m}$ above sea level. It is circular, measuring c. $26 \mathrm{~m}$ in diameter, while its rim reaches a maximum height of c. $1 \mathrm{~m}$.

The material is dominated by pebbly gravel, with very scattered vegetation.

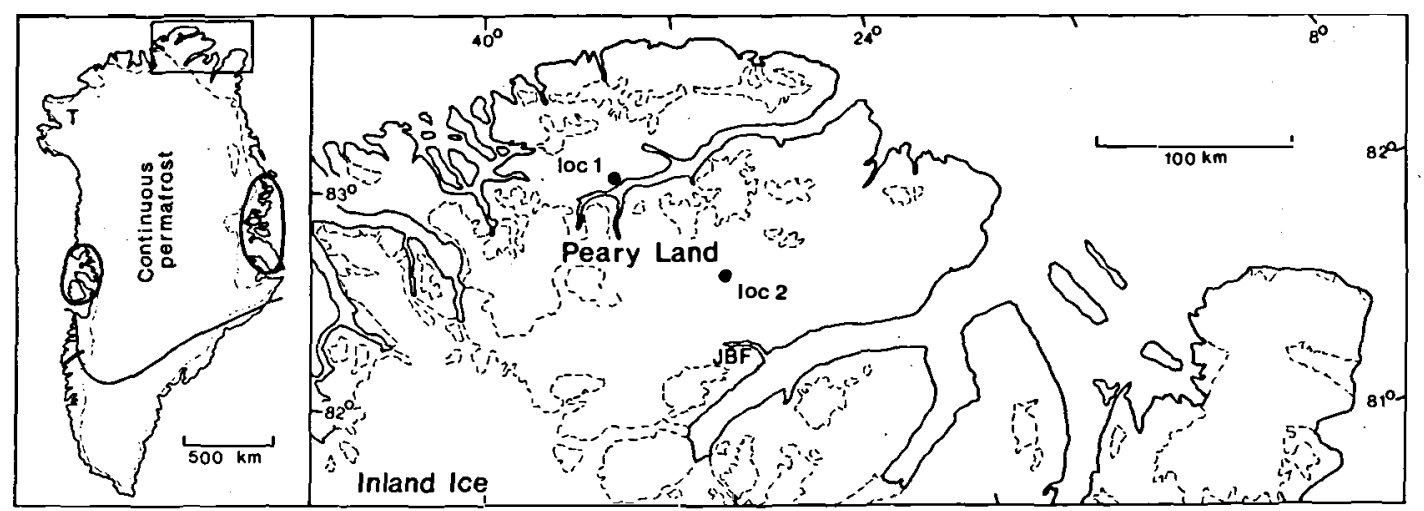

Fig. 1. Map showing the two pingo-localities (loc $1 \& 2$ ). The two circled areas on left part of figure indicates the previous known distribution of pingos in Greenland. Southem limit for continuous permafrost after Weidick (1968).

T: Thule, JBF: Jørgen Brønlund Fjord. 


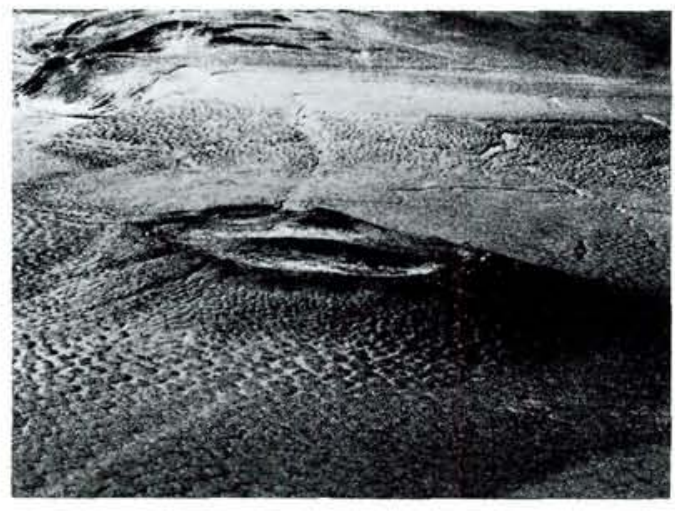

Fig. 2. The pingo in Vølvedal. Photo from helicopter by Stig Schack Pedersen.

Loc. 2: Børglum Elv valley, $82^{\circ} 25^{\prime} \mathrm{N}, 30^{\circ} 16^{\prime} \mathrm{W}$.

A group of three pingos, or pingo-like features are found (see fig. 3). The valley has a northwest-southeast trend, it is U-formed and situated in a plateau landscape.

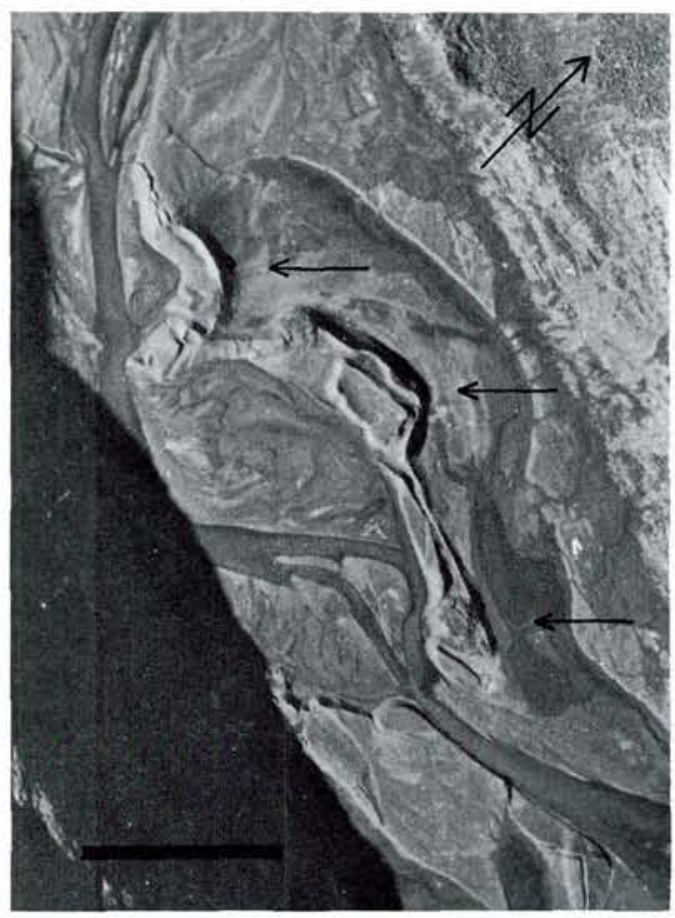

Fig. 3. The three pingos or pingo-like features in the Børglum Elv valley, indicated by arrows. The bar measures c. $200 \mathrm{~m}$ (c. 1:10.000).

Geodetic Institute, Copenhagen, enlarged part of photo 256-V nr. 499, 1961. (Reproduced with permission from the Institute: A.135/83). Copyright.
The pingos are collapsed and somewhat eroded by the Børglum Elv river. The western pingo appears to have been circular, measuring c. $100 \mathrm{~m}$ in diameter. Its rim attained a height of c. $9 \mathrm{~m}$. The central and eastern ones are more irregular in form, the central one reached c. $15 \mathrm{~m}$ in height. The pingos are somewhat coalesced.

The material consists of glaciofluvial pebbly and cobbly gravel. A two metres high profile in the western pingo consists of fining upwards gravel. The area is virtually devoid of vegetation.

\section{Discussion and conclusion}

Pingos are subdivided into closed-system pingos thought to grow by cryostatic pressure and open-system pingos thought to grow by artesian pressure (Washburn 1979). The pingos from Peary Land are referred to the second category on the basis of their position in valley bottoms.

Collapsed pingos are not necessarily indicative of environmental changes, as the growth can lead to self-destruction. Changes in drainage pattern connected with relative Holocene land emergence in the area may also be important.

In Greenland pingos are known to occur on the central west and east coast (Rosenkrantz 1950; Müller 1959; fig. 1). Müller concluded, that pingos occur where the permafrost is continuous but thinning out.

Outside Greenland non-fossil pingos occur in Svalbard, in USSR, in Alaska and Canada. Washburn (1979) have mapped their distribution in Canada. Several occurrences are reported from the Canadian arctic islands. Three of them are from the northern part of Ellesmere Island, where the climatic conditions resembles those in Peary Land.

In conclusion it may be stated that pingos are by far most common in the southern part of the zone with continuous permafrost, but they also occur, although very rarely, in the northernmost parts of Canada and Greenland.

Acknowledgements. This paper is published with the permission of the Director of the Geological Survey of Greenland. S. S. Pedersen and C. Marcussen are thanked for good fellowship in the field. I am indebted to John Miller, Svend Funder and Stuart Watt for having read the manuscript critically. 


\section{Dansk sammendrag}

To fund af pingoer fra Nordgronland er de forst beskrevne fra regionen. Pingoerne var sammenstyrtede. De formodes at have tilhørt den åbne type, dannet $\mathrm{i}$ forbindelse med artesisk tryk, idet de ligger $i$ dalbunde. Pingoer forekommer meget spredt $i$ den nordlige del af den kontinuerlige permafrostzone.

\section{References}

Fristrup, B. 1952: Physical Geography of Peary Land. I. Meteorological Observations for Jørgen Brønlund Fjord. Meddr Grønland 127, 4, 143 pp.
Müller, F. 1959: Beobachtungen über Pingos. Detailuntersuchungen in Ostgrönland und in der Kanadischen Arktis. Meddr Grønland 153, 3, 127 pp.

Roethlisberger, H. 1961: The applicability of seismic refraction soundings in permafrost near Thule, Greenland. Tech. Rep. Cold Reg. Res. Engng. Lab. 81, 19 pp. + 15 pp., appendix.

Rosenkrantz, A. 1950: Dyndvulkaner. In Birket-Smidt, K. Grønlandsbogen 1, 112-113. Copenhagen: Schultz.

Washburn, A. L. 1979: Geocryology, 406 pp. London: Edward Arnold.

Weidick, A. 1968: Observations on some Holocene glacier fluctuations in West Greenland. Meddr Grønland 165, 6, $202 \mathrm{pp}$. 